\title{
GÊNESE DO DIAMANTE: UMA REVISÃO dOS CONHECIMENTOS ATUAIS *
}

D.P.Svisero

A gênese do diamante é um tema que vem empolgando os pesquisadores há longa data. Garimpado desde 2.000 A.C. foi ele encontrado "in situ" pela primeira vez em 1871, na África do Sul, em um tipo particular de peridotito que recebeu o nome de kimberlito. Durante um século, aproximadamente, o kimberlito foi considerado a rocha matriz do diamante. Em 1955, um grupo de cientistas da General Eletric Co. (BUNDY et al., 1955; Nature, 176:51-54) sintetizou diamantes a partir de grafita e níquel como catalizador, em temperaturas de $1200^{\circ} \mathrm{C}$ e pressões de $40 \mathrm{kbar}$. Como essas condições equivalem a profundidades da ordem de $150 \mathrm{~km}$, ficou provado que o diamante cristaliza no manto superior.

Com o desenvolvimento do Projeto Moho no início dos anos sessenta, alguns pesquisadores passaram a investigar as inclusões cristalinas do diamante. 0 raciocínio que faziam era simples: sendo o diamante mantélico, suas inclusões singenéticas constituem fragmentos de rochas do manto e podem revelar informações sobre sua gênese. Na verdade, havia uma literatura vasta sobre essas inclusões, mas o emprego da difração de raios $\mathrm{X}$ e da microssonda eletrônica restrıngiu o número de fases primárias e ao mesmo tempo revelou outras até então desconhecidas. No final dos anos setenta estava bem estabelecido que o diamante, independentemente da sua procedência geográfica, possui dois grupos distintos de iclusões singenéticas a saber: a) grupo peridotítico, o mais freqüente, constituído pela olivina, enstatita, diopsídio, magnésio cromita e magnésio ilmenita; e b) grupo eclogftico reunindo onfacita, piropo-almandina, ferro cromita, ilmenita, coesita, rutilo, coríndon e cianita. Sulfetos e o próprio diamante ocorrem nos dois grupos. $O$ estabelecimento desses dois grupos paragenéticos distintos bem como a presença de diamantes em xenólitos de eclogitos e peridotitos em

\footnotetext{
*Apoio CNPq e FAPESP.

Departamento de Mineralogia e Petrologia, Instituto de Geociências, USP.
} 
kimberlitos, motivou a procura de outras fontes além da tradicional kimberlítica. Durante a $3^{\mathrm{a}}$ Conferência Internacional de Kimberlitos realizada na França em 1982, foi comunicada a descoberta de lamproftos diamantfferos na Austrália. Uma das intrusões, Argyle, continha a maior reserva de diamante em uma jazida individual com teores de 5 quilates/tonelada. A essas alturas, já haviam várias indicações de que o diamante não se cristaliza no magma kimberlítico e/ou lamprof́tico. Trabalhos geocronológicos de Richardson e vários colaboradores provaram essa assertiva. Utilizando os métodos Rb/Sr e Sm/Nd (Nature 310:198-202, 1984), eles dataram crômio piropos (grupo peridotítico) extraídos de diamantes dos Kimberlitos Finsch e Kimberley, duas minas clássicas da África do Sul com idades bem conhecidas de $90 \mathrm{Ma}$., obtendo para as inclusões idades de 3,3 Ga. Essa discrepância de idades mostrou claramente que o diamante é apenas um xenocristal e o kimberlito seu veículo de transporte até a crosta. Pouco depois (Nature, 332:623-626, 1986) foram datados onfacita e piropoalmandina (grupo eclogitico) utilizando diamantes de kimberlitos e lamproftos. Para o Kimberlito Premier de idade 1,1-1,2 Ga., as inclusões revelaram idade de 1,15 Ga. indicando que nesse caso o diamante é contemporâneo à inclusão. Já para o Lamprofto Argyle de idade 1,1-1,2 Ga., as iclusões são mais antigas com valores de $1,58 \mathrm{Ga}$.

Diamantes peridotíticos possuem razões isotópicas $\delta^{13} \mathrm{C}$ constantes, sugerindo derivação a partir de fontes homogêneas no manto. Cristalizados precocemente no Arqueano, via oxidação do $\mathrm{CH}_{4}$ ou redução do $\mathrm{CO}_{2}$ sob certas condições de $\mathrm{fO}_{2}$ permaneceram estocados sob os crátons onde pressões altas e temperaturas relativamente moderadas garantiram sua preservação até serem alçados por kimberlitos cretácicos. Aparentemente, os diamantes eclogíticos possuem história geológica bem diferente. Suas razões $\delta^{13} \mathrm{C}$ sugerem fontes de carbono heterogêneas, provavelmente crustais, que teriam alcançado o manto por meio de subducção de placas continentais. Possuem, conseqüentemente, idades variáveis sendo mais novos do que os diamantes peridotíticos.

A importância das informações reveladas pelo estudo das inclusões do diamante não se restringe a esse mineral e aos problemas de sua gênese. Elas possuem implicações mais abrangentes entre as quais destacamos duas: 1) o fato do diamante ser em sua maior parte arqueano e ter permanecido sob a litosfera continental durante mais de 3,0 Ga., só pode ser explicado admitindo-se que essa litosfera já fosse suficientemente espessa, algo acima de $120 \mathrm{~km}$, caso contrário, o diamante não teria permanecido em equilíbrio; 2) a existência de diamantes, originados a partir de carbono crustal reciclado pelo movimento de placas continentais, constitui uma evidência forte de que esse tipo de tectônica já era atuante no Proterozóico.

Por outro lado, descobertas recentes de pseudomorfos de grafita segundo diamante em peridotitos do tipo alpino no Marrocos (PEARSON et al., 1989; Nature, 338:60-62); de 
diamantes inclusos em granadas de rochas metamórficas crustais (SOBOLEV, et al. 1990; Nature, 343:742-746); bem como as idéias de Shibata (Conferência no IG/USP, Dez. 1991) de que o carbonado (diamante policristalino) é de origem crustal, sendo formado durante colisões continentais, ampliaram ainda mais o universo das questóes relativas à gênese do diamante. O tema é complexo e, ao que tudo indica, não está restrito ao manto como se admitia até alguns anos atrás. 